\title{
Gender Based Mood Analysis on Purchase of Wrist Watches in Bangalore,
} Karnataka

\section{Satheeshkumar Rangasamy ${ }^{\rtimes}$ \\ Sushma Rawath ${ }^{2}$ iD \\ Gokula Krishnan $\mathbf{S}^{s}$ (iD Raja Gopal D ${ }^{4}$ iD}

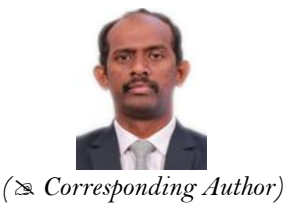

'Professor, Department of M.B.A, Surana College, Kengeri Campus, KST, Bangalore, Karnataka, India. Email: satheeshk5282@yahoo.com Tel:9487271346

'Assistant Professor, Department of M.B.A, Surana College, Kengeri Campus, KST, Bangalore, Karnataka,

Email:sushma.rawath88@gmail.com Tel:9482413278

${ }^{*}$ Associate Professor - HR, Analytics \& Entrepreneurship, Department of Management Studies (MBA), Acharya

Institute of Technology, India.

Email:prof.golulakrishnans@gmail.com Tel:9489766214

'Assistant Professor, Department of Computer Application, Vivekanandha College of Arts and Science for Women,

Autonomous, Namakkal District, Tamilnadu, India.

Email:sakthiraj2782007@gmail.com Tel:8015225345

\section{Abstract}

Buying behavior and spending pattern are highly influenced by mood of the customer in general. Mood shapes person's attention, choices of the product and purchasing decision though the life span of mood is short. Organizations must find out means and measures to trigger customers' mood into positive that in turn will induce them to buy the product. This article focuses on gender-based mood analysis on purchase of wrist watches. The researcher has adopted structured questionnaire to get the primary responses from the respondent to study how far mood varies among the genders on purchase of wrist watches and researcher has made framework to highlight the order of the measures / attributes to be followed to trigger the customers' mood. The researcher has applied descriptive statistics to present the key aspects of mood of the respondents and applied ranking method to identify the attribute that trigger the mood of the potential customers. It is concluded that the attribute of demonstration of wrist watches features in specific to men and women, building a community group and attribute of need, elite and self-esteem, sense of accomplishment, aspiration, and marketing communication tactics are some of the significant attributes that trigger the customers to buy wrist watches from highest order to lowest order.

Keywords: Gender based, Purchase decision, Mood analysis, Triggering attributes, Marketing communication and cognition. JEL Classification: MoO.

Citation | Satheeshkumar Rangasamy; Sushma Rawath; Gokula Krishnan S; Raja Gopal D (2021). Gender Based Mood Analysis on Purchase of Wrist Watches in Bangalore, Karnataka. Asian Journal of Social Sciences and Management Studies, 8(3): 61-68.

History:

Received: 13 May 202

Revised: 18 June 2021

Accepted: 20 July 202

Published: 16 August 2021

Licensed: This work is licensed under a Creative Commons Attribution 3.0 License $(\mathrm{cc})$ (er

Publisher: Asian Online Journal Publishing Group
Acknowledgement: All authors contributed to the conception and design of the study.

Funding: This study received no specific financial support.

Competing Interests: The authors declare that they have no conflict of interests.

Transparency: The authors confirm that the manuscript is an honest, accurate, and transparent account of the study was reported; that no vital features of the study have been omitted; and that any discrepancies from the study as planned have been explained.

Ethical: This study follows all ethical practices during writing.

\section{Contents}

1. Introduction of the Study

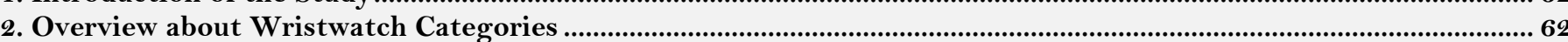

3. Review of Literature..... 62

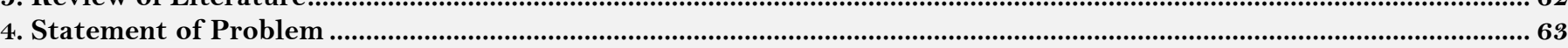

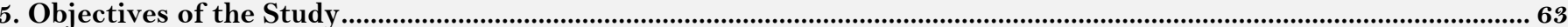

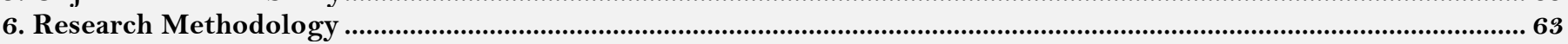

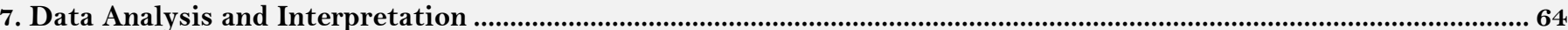

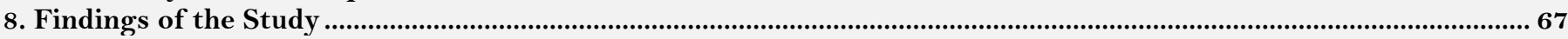

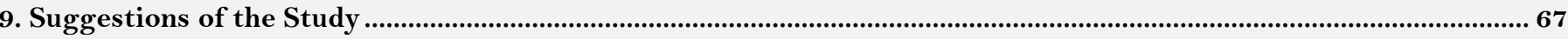

10. Conclusion................67

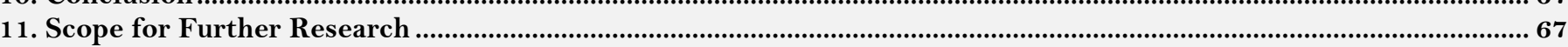

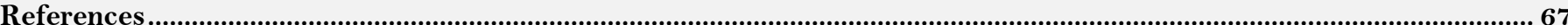




\section{Contribution of this paper to the literature}

This study contributes to existing literature by focusing on gender-based mood analysis on purchase of wrist watches.

\section{Introduction of the Study}

Positive mood inspires good thoughts and negative moods can lead to put off doom loop in which an individual perpetually delays important tasks. Mood shapes person's attention, choices of the product and purchasing decision though the life span of mood is short. Organizations must find out means and measures to trigger customers' mood in to positive that in turn will induce them to buy the product.

Gerard Zaltman in his book "How customer think: Essential insights into the mind of Market" pointed out that ninety five percent of cognition happens outside of our conscious brain and rest happen inside of our sub conscious and emotional brains. So, Marketers must trigger emotional brains. Zaltman (2016) study showed that $95 \%$ of our cognition happens in our emotional brain.

Table-1. Market share growth rate of different segments including jewelry and watches.

\begin{tabular}{l|c|c|c|c}
\multicolumn{4}{c}{ Table-1. Market share growth rate of different segments including jewelry and watches. } \\
\hline Particulars & $\mathbf{2 0 1 2}$ & $\mathbf{2 0 1 7}$ & $\mathbf{2 0 2 2}(\mathbf{E x p})$ & CAGR (2017-22) \\
\hline Food \& Grocery & $67.5 \%$ & $66.7 \%$ & $65.8 \%$ & $11.4 \%$ \\
\hline Fashion & $9.5 \%$ & $9.1 \%$ & $8.9 \%$ & $10.7 \%$ \\
\hline Jewelry \& Watches & $7.3 \%$ & $7.7 \%$ & $8.2 \%$ & $13.7 \%$ \\
\hline Consumer Electronics & $5.2 \%$ & $5.9 \%$ & $6.8 \%$ & $12.0 \%$ \\
\hline Home \& Living & $4.2 \%$ & $4.3 \%$ & $4.4 \%$ & $13.3 \%$ \\
\hline Pharmacy \& Wellness & $2.8 \%$ & $2.9 \%$ & $3 \%$ & $11.9 \%$ \\
\hline Others & $3.6 \%$ & $3.2 \%$ & $3.1 \%$ & $10.4 \%$ \\
\hline Total & 322 & 575 & 979 & $11.2 \%$ \\
\hline
\end{tabular}

Table 1 present details about market share growth rate of different sectors including jewelry and watches and it provides the picture of constant growth of jewelry and watches sector. It is noted that jewelry and watches sector had $7.3 \%$ market share in the year 2012 and it increased to the tune of $7.7 \%$ in the year 2017 and it is expected to grow as $8.2 \%$ in the year 2022 and it has $13.7 \%$ CAGR between 2017 and 2022 .

\section{Overview about Wristwatch Categories}

The wrist watches market in India can be ordered into three general categories based on cost. The first category of watches is the mass value section comprising of watches estimated worth lower than Rs. 1,000 which are sold by the sloppy players. The mass value section watches are dominated by Titan, PA Time enterprises and Citizen. Sonata (for people), and Zoop (kids) are brands of Titan with their dominant part presence in mass portion. Maxima from PA Time businesses and Q\&Q from Citizen are different brands in mass segment.

The second category of watches are the mid-value segment of watches. This category watches price ranges from Rs. 1,000 to Rs.10, 000. This section likewise has design watches from global players like Diesel, Esprit, Fossil, Giordano, Tommy Hilfiger, Guess, Kenneth Cole, Police and so on.

The third category of watches are the top-notch fragment watches which has the estimated worth of above Rs. 10,000. The top-notch fragment wristwatch market in India can be additionally partitioned into three value classifications: reasonable extravagance, elegance, and super extravagance. The extravagance section which is essential for premium lot worth ranges between Rs. 1, 00,000 and Rs. 10, 00,000. Large numbers of these top-ofthe-line watches are frequently gold plated, precious stone studded and utilized as left arm gems. Brands ranges from superior, moderate extravagance to eminence value groups. Models are Guess Collection, Seiko, Tissot, Xylys, Dior, Longines, Rado, Tag Heuer, Harry Winston, IWC, JLC, Patek Philippe, Ulysse Nardin, Breitling, Cartier, Montblanc, Omega, and Rolex, so on.

Elegance category of watches includes brand like Daniel, Van Heusan, Titan Raga, Meister Singer and Fossil. Super extravagance category of watches includes brand like Movado Ultra, Micael Kors, Tissot, Rolex, Tag Heuer, Louis Moinet Memories, Corum.

\section{Review of Literature}

Gasper (2003) explored how mood influences flexible thinking. Her research suggests that individuals in sad moods are more flexible than those in happy moods when tasks proved difficult and unpleasant. Individuals in sad moods were more likely to try new and different approaches to solve a problem than those in happy moods.

Research by Gardner and Ronald (1986) demonstrates that mood states have an impact on and are impacted by consumers' activities during the buying process. Finally, we should consider the impact of marketer-induced moods upon product evaluations. If marketers manipulate mood, they will improve or reduce the likelihood that consumers use of information contained in their communications.

Gardner and Ronald (1986) found a relationship between mood states, processing style, and product category selected for evaluation by consumers.

Clark and Teasdale (1985) found that women are more likely than men to recall pleasant words when they in a happy mood and less likely to recall pleasant information when they are in a depressed mood. Several explanations for the interaction of mood and gender have been suggested. Clark and Teasdale use an associative network model to explain the gender difference and suggest that women may have stronger links between mood and cognitive nodes in memory, either because they are used more frequently or more intensely.

An alternative explanation of mood-gender interaction is proposed by Rothkopf and Blaney (1991). The authors suggest that mood congruent recall requires at least some awareness of one's own mood state. Further, women are superficially more likely to be aware of (and effected by) their own mood state in recall of information. In general, the psychological literature suggests that gender differences may have both a main effect on perceived time and a moderating effect on mood's influence. 


\section{Statement of Problem}

It is evident from the reviews that effects of mood of the human being have been felt extensively in the buying process. Rook and Meryl (1986) have demonstrated that consumer's mood impacts the amount of money spent on impulse purchases. Various studies have been carried out to understand the effect of mood, cognition, and emotion of customers in the buying process and product purchase. The researcher identifies research gap that there are also differences in the purchase pattern among the different gender. Hence, it prompted the researcher to undertake the study on gender-based mood analysis in purchase of wrist watches.

\section{Objectives of the Study}

1. To identify the factors that influencing the customers to purchase of wrist watches.

2. To find out reasons for buying a new wristwatch.

3. To analyze customers opinion on point of cognition.

4. To evaluate the measures / attributes that trigger customers' mood to buy the wrist watches.

\section{Research Methodology}

\subsection{Type of Research Design}

Researcher has adopted descriptive research and presented the research work in a descriptive manner in terms of market share growth rate of different sectors including jewelry and watches, overview about wristwatch categories, measures / attributes that trigger customers' mood to buy the wrist watches and presented the outcome of the research work with descriptive analysis and ranking method.

\begin{tabular}{|c|c|c|}
\hline Particulars & No. of Respondent & Percentage \\
\hline \multicolumn{3}{|l|}{ Area of Residence } \\
\hline Urban & 125 & 73 \\
\hline Semi Urban & 24 & 14 \\
\hline Rural & 23 & 13 \\
\hline Total & 172 & 100 \\
\hline \multicolumn{3}{|c|}{ Gender of Respondents } \\
\hline Male & 80 & 47 \\
\hline Female & 92 & 53 \\
\hline Total & 172 & 100 \\
\hline \multicolumn{3}{|l|}{ Age of Respondents } \\
\hline Up to 25 years & 111 & 65 \\
\hline $26-30$ years & 14 & 8 \\
\hline 31-35 years & 18 & 10 \\
\hline $36-40$ years & 15 & 9 \\
\hline Over 40 years & 14 & 8 \\
\hline Total & 172 & 100 \\
\hline \multicolumn{3}{|c|}{ Academic Qualification } \\
\hline School Level & 2 & 1 \\
\hline Undergraduate & 31 & 18 \\
\hline Postgraduate & 120 & 70 \\
\hline Professional & 17 & 10 \\
\hline Others - Specify & 2 & 1 \\
\hline Total & 172 & 100 \\
\hline \multicolumn{3}{|c|}{ Present Employment Status } \\
\hline Govt. Employee & 0 & 0 \\
\hline Private Employee & 48 & 28 \\
\hline Businessmen & 8 & 5 \\
\hline Housewife & 4 & 2 \\
\hline Professional & 16 & 9 \\
\hline Student & 91 & 53 \\
\hline Others - Specify & 5 & 3 \\
\hline Total & 172 & 100 \\
\hline \multicolumn{3}{|c|}{ Monthly Family Income } \\
\hline Below Rs.25000 & 67 & 39 \\
\hline Rs. 25001-35000 & 26 & 15 \\
\hline Rs. 35001-45000 & 20 & 12 \\
\hline Rs. 45001-55000 & 17 & 10 \\
\hline Above Rs. 55000 & 42 & 24 \\
\hline Total & 172 & 100 \\
\hline \multicolumn{3}{|l|}{ Type of Family } \\
\hline Joint family & 60 & 35 \\
\hline Nuclear & 112 & 65 \\
\hline Total & 172 & 100 \\
\hline \multicolumn{3}{|c|}{ Number of Members in the Family } \\
\hline Below 3 Members & 16 & 9 \\
\hline $3-5$ Members & 129 & 75 \\
\hline Above 5 Members & 27 & 16 \\
\hline Total & 172 & 100 \\
\hline
\end{tabular}




\subsection{Sampling Method and Size}

Researcher has adopted convenient sampling method and has taken 172 respondents as sample size assuming $95 \%$ confidence level with a five percent margin of error and 100000 as the estimated population size. Researcher has referred Watson (2001), how to determine a sample size: Tip sheet \#60, University Park, PA: Penn State Cooperative Extension to finalize the given sample size.

\subsection{Source of Data}

Researcher has collected the data from primary data and secondary data from various source.

\subsection{Instruments for Data Collection} form.

Researcher has collected the responses from respondents using the structured questionnaire through Google

\subsection{Tools for Data Analysis}

Descriptive analysis and weighted average ranking score method are the tools for data analysis.

\subsection{Limitations of the Study}

1. Present study is subject to respondents' bias.

2. Study findings are applicable to Bangalore only.

\section{Data Analysis and Interpretation}

\section{Interpretation}

Table 2 presents about the demographic profile of the respondents. It is found that $73 \%$ of the respondents are belonging to urban area, $53 \%$ of the respondents are Female, $65 \%$ of the respondents belong to the age group of lesser than 25 years old and 70 of the respondents are Postgraduates. $28 \%$ of respondents are private employees and $39 \%$ of the respondents belong to the income group of below Rs.25000. $65 \%$ of the respondents belong to nuclear family and $75 \%$ of the respondents said that they have 3-5 members in their family.

Table-3. Factors that respondents consider for purchase of wrist watches.

\begin{tabular}{c|l|c|c}
\hline Sl. No & $\begin{array}{l}\text { Factors that customers consider for purchase of } \\
\text { Wrist Watches }\end{array}$ & No. of Respondents & Percentage \\
\hline 1 & Brand image & 60 & 35 \\
\hline 2 & Price & 23 & 13 \\
\hline 3 & Appearance & 28 & 16 \\
\hline 4 & Water resistance & 3 & 2 \\
\hline 5 & Durability & 22 & 13 \\
\hline 6 & Long warranty period & 13 & 8 \\
\hline 7 & Technical specifications & 21 & 12 \\
\hline 8 & After sales service & 2 & 1 \\
\hline & Total & $\mathbf{1 7 2}$ & $\mathbf{1 0 0}$ \\
\hline
\end{tabular}

\section{Interpretation}

It is found from the Table 3 that $35 \%$ of the respondents said that brand image is first factor that they consider buying the wrist watches and $16 \%$ and $13 \%$ of the respondents said that they consider appearance and durability respectively to buy the wrist watches. Only $1 \%$ of the respondents said that they consider after sales service as the factor to buy the wrist watches.

Table-4. Reasons for buying a new wristwatch.

\begin{tabular}{c|l|c|c}
\hline Sl No. & Reason for buying a new wristwatch & No. of Respondents & Percentage \\
\hline 1 & Requirement & 43 & 25 \\
\hline 2 & Style & 50 & 29 \\
\hline 3 & Better model available in the market & 16 & 9 \\
\hline 4 & Gifting & 1 & 1 \\
\hline 5 & Luxury & 25 & 15 \\
\hline 6 & Convenience & 37 & 22 \\
\hline & Total & $\mathbf{1 7 2}$ & $\mathbf{1 0 0}$ \\
\hline
\end{tabular}

\section{Interpretation}

It is studied from the Table 4 that $29 \%$ of the respondents said that style is the main reason for buying a new wrist watch and only $1 \%$ of the respondents said that they buy the wrist watches for gifting purpose.25\% of the respondents purchased for the sake of requirement, $22 \%$ purchased for convenience, $15 \%$ purchased for luxury and $9 \%$ for better models. It is inferred that most of the respondents purchased for styles.

Table-5. Category of wrist watches that respondents wish to buy

\begin{tabular}{c|l|c|c}
\hline S1. No & Category of Wrist Watches that Customers wish to buy & No. of Respondents & Percentage \\
\hline 1 & Professional & 25 & 15 \\
\hline 2 & Fashionable & 46 & 27 \\
\hline 3 & Quality-Oriented & 27 & 16 \\
\hline 4 & Sporty & 4 & 2 \\
\hline 5 & Multi-functional & 20 & 12 \\
\hline 6 & Digital Watch & 9 & 5 \\
\hline 7 & All-in-one & 41 & 24 \\
\hline & Total & $\mathbf{1 7 2}$ & $\mathbf{1 0 0}$ \\
\hline
\end{tabular}




\section{Interpretation}

It is concluded from the Table 5 that $27 \%$ of the respondents wish to buy for fashionable and $24 \%$ of the respondents said that all in one category of watches are the next preference.

Table-6. Respondents' preferred price band on the selection of wrist watches.

\begin{tabular}{c|l|c|c}
\hline \multicolumn{1}{|c|}{ Table-6. Respondents' preferred price band on the selection of wrist watches. } \\
Sl. No & $\begin{array}{l}\text { Preferred Price Band of Wrist Watches that } \\
\text { Customers wish to buy }\end{array}$ & No. of. Respondents & Percentage \\
\hline 1 & Up to Rs.5000 & 91 & 53 \\
\hline 2 & Rs.5001-Rs.10000 & 40 & 23 \\
\hline 3 & Rs.10001- Rs.15000 & 8 & 5 \\
\hline 4 & Rs.15001- Rs.20000 & 20 & 12 \\
\hline 5 & Rs.20001- Rs.25000 & 2 & 1 \\
\hline 6 & Above Rs.25000 & 11 & 6 \\
\hline & Total & $\mathbf{1 7 2}$ & $\mathbf{1 0 0}$ \\
\hline
\end{tabular}

\section{Interpretation}

It is noted from the Table 6 that $53 \%$ of the respondents said that they preferred price band on the selection of wrist watches fall up to Rs.5000 and only $1 \%$ of the respondents said that their preferred price band on the selection of wrist watches between Rs.20001 to Rs.25000. 23\% of the respondents preferred the price brand between 50001 to 10000 and $16 \%$ of the respondents wish to buy for quality-oriented reasons. $15 \%$ of the respondents bought for professional reasons.

Table-7. Respondents' Opinion on Point of Cognition.

\begin{tabular}{c|l|c|c}
\hline Sl. No. & Opinion on point of cognition & No. of Respondents & Percentage \\
\hline 1 & Happens outside of individuals' conscious brain & 90 & 52 \\
\hline 2 & Inside of individuals sub conscious and emotional brains & 82 & 48 \\
\hline & Total & $\mathbf{1 7 2}$ & $\mathbf{1 0 0}$ \\
\hline
\end{tabular}

\section{Interpretation}

It is identified from the Table 7 that $52 \%$ of the respondents have an opinion that their point of cognition happens outside of individuals conscious brain and $48 \%$ of the respondents have an opinion that their point of cognition happens inside of individuals sub conscious and emotional brains.

\begin{tabular}{c|l|c|c} 
Table-8. Respondents' opinion on whether customers' attention can be shaped by triggering of emotional brains and mood. \\
\hline Sl. No & Respondents Opinion & No. of. Respondents & Percentage \\
\hline 1 & Yes & 154 & 90 \\
\hline 2 & No & 18 & 10 \\
\hline & Total & $\mathbf{1 7 2}$ & $\mathbf{1 0 0}$ \\
\hline
\end{tabular}

\section{Interpretation}

It is observed from the Table 8 that $90 \%$ of the respondents have an opinion that customers' attention can be shaped by triggering of emotional brains and mood and $10 \%$ of the respondents have an opinion that customers' attention can't be shaped by triggering of emotional brains and mood.

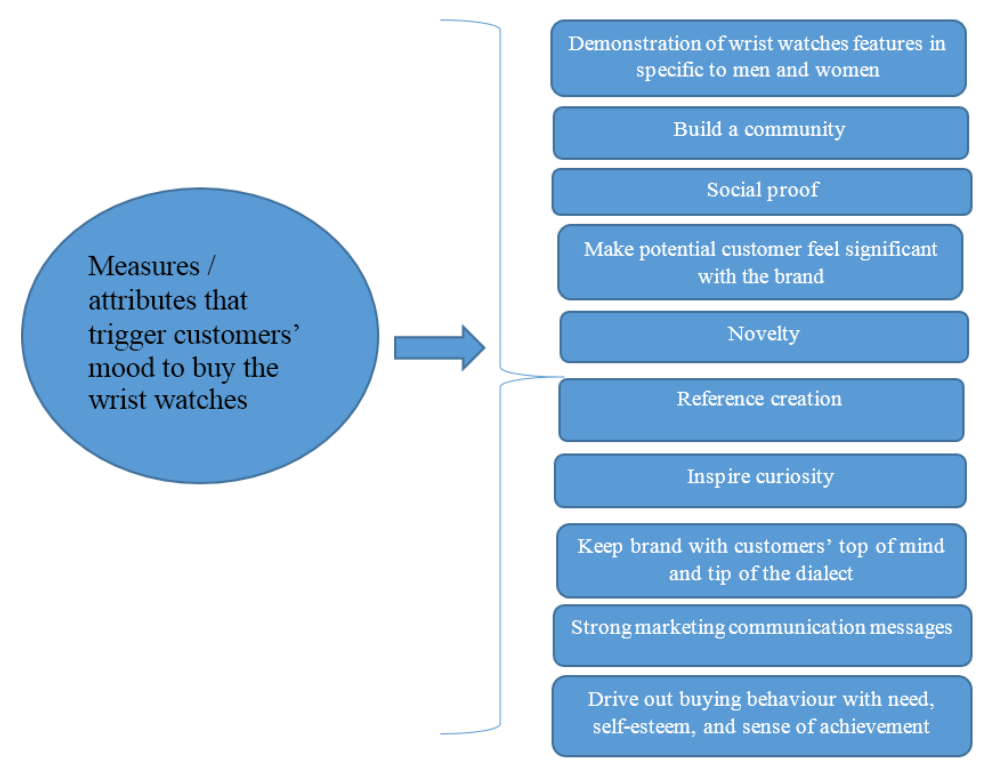

Figure-1. Framework on Measures / Attributes that trigger customers' mood to buy the wristwatch.

\section{Interpretation}

Figure 1 provides the framework on measures / attributes that trigger customers' mood to buy the wristwatch. The organization in the given sector must adopt the above measures / attributes to trigger the customers' mood to make them to buy the wristwatch. 


\begin{tabular}{|c|c|c|c|c|c|c|c|c|c|c|c|c|c|c|c|c|c|c|c|c|c|c|}
\hline $\begin{array}{l}\dot{Z} \\
\bar{n}\end{array}$ & $\begin{array}{l}\text { Measures / attributes that } \\
\text { trigger customers' mood to buy } \\
\text { the wrist watches }\end{array}$ & 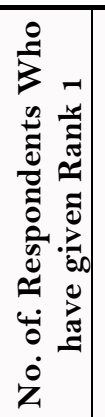 & 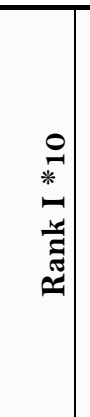 & 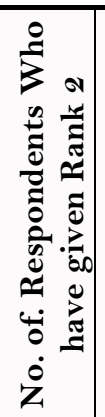 & 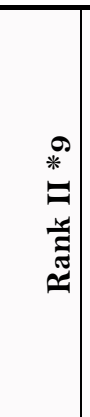 & 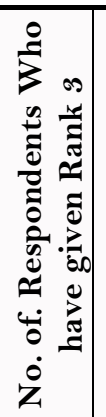 & 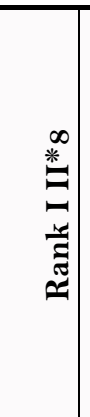 & 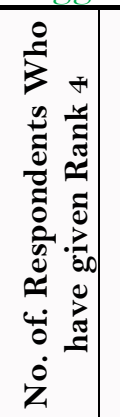 & 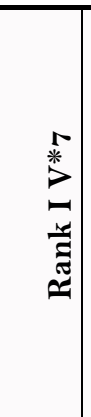 & 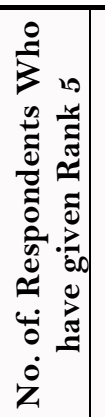 & 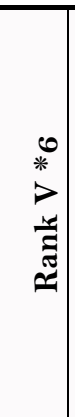 & 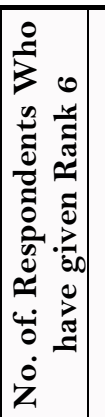 & 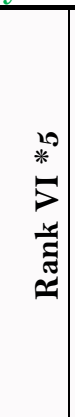 & 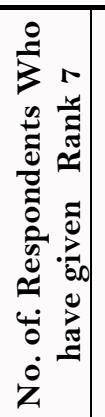 & 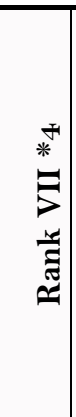 & 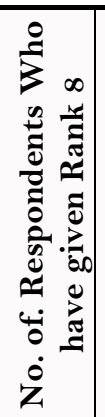 & 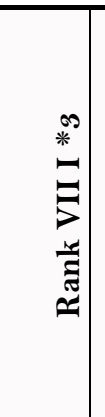 & 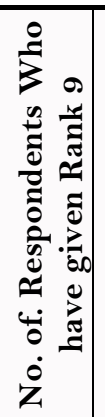 & 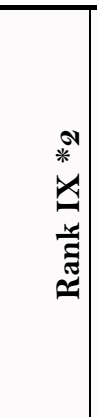 & 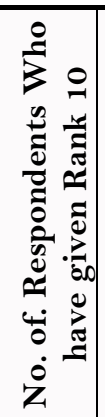 & 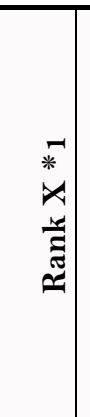 & 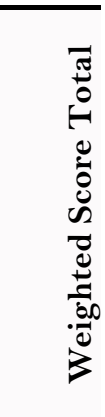 \\
\hline 1 & $\begin{array}{l}\text { Drive out buying behaviour with } \\
\text { need, self-esteem, sense of } \\
\text { achievement }\end{array}$ & 9 & 90 & 3 & 27 & 3 & 24 & 4 & 28 & 3 & 18 & 2 & 10 & 6 & 24 & 28 & 84 & 46 & 92 & 68 & 68 & 569 \\
\hline 2 & Novelty & 4 & 40 & 6 & 54 & 5 & 40 & 3 & 21 & 8 & 48 & 8 & 40 & 9 & 36 & 23 & 69 & 73 & 146 & 33 & 33 & 666 \\
\hline 3 & Inspire curiosity & 4 & 40 & 7 & 63 & 1 & 8 & 6 & 42 & 2 & 12 & 15 & 75 & 14 & 56 & 33 & 99 & 40 & 80 & 50 & 50 & 647 \\
\hline 4 & $\begin{array}{l}\text { Demonstration of wrist watches } \\
\text { features in specific to men \& } \\
\text { women }\end{array}$ & 4 & 40 & 4 & 36 & 4 & 32 & 4 & 28 & 11 & 66 & 12 & 60 & 12 & 48 & 26 & 78 & 59 & 118 & 36 & 36 & 678 \\
\hline 5 & Social proof & 2 & 20 & 7 & 63 & 8 & 64 & 4 & 28 & 6 & 36 & 13 & 65 & 2 & 8 & 37 & 111 & 54 & 108 & 39 & 39 & 675 \\
\hline 6 & Reference creation & 0 & 0 & 5 & 45 & 7 & 56 & 6 & 42 & 4 & 24 & 12 & 60 & 9 & 36 & 22 & 66 & 76 & 152 & 31 & 31 & 653 \\
\hline 7 & $\begin{array}{l}\text { Make potential customer feel } \\
\text { significant with the brand }\end{array}$ & 4 & 40 & 10 & 90 & 4 & 32 & 2 & 14 & 8 & 48 & 18 & 90 & 1 & 4 & 33 & 99 & 41 & 82 & 51 & 51 & 671 \\
\hline 8 & Build a community & 5 & 50 & 5 & 45 & 7 & 56 & 4 & 28 & 3 & 18 & 7 & 35 & 23 & 92 & 20 & 60 & 60 & 120 & 38 & 38 & 676 \\
\hline 9 & $\begin{array}{l}\text { Keep brand with customers' top of } \\
\text { mind and tip of the dialect }\end{array}$ & 4 & 40 & 10 & 90 & 6 & 48 & 2 & 14 & 1 & 6 & 9 & 45 & 13 & 52 & 34 & 102 & 34 & 68 & 59 & 59 & 637 \\
\hline 10 & $\begin{array}{l}\text { Strong marketing communication } \\
\text { messages }\end{array}$ & 9 & 90 & 8 & 72 & 2 & 16 & 3 & 21 & 1 & 6 & 6 & 30 & 7 & 28 & 20 & 60 & 45 & 90 & 71 & 71 & 585 \\
\hline
\end{tabular}


Table-9.2. Measures / Attributes that trigger customers' mood to buy the wrist watches.

\begin{tabular}{|c|c|c|c|}
\hline Sl. No & $\begin{array}{l}\text { Measures/ Attributes that trigger customers' mood to buy the } \\
\text { wrist watches }\end{array}$ & Total Weighted Score & Rank \\
\hline 1 & $\begin{array}{l}\text { Demonstration of wrist watches features in specific to men and } \\
\text { women }\end{array}$ & 678 & I \\
\hline 2 & Build a community & 676 & II \\
\hline 3 & Social proof & 675 & III \\
\hline 4 & Make potential customer feel significant with the brand & 671 & IV \\
\hline 5 & Novelty & 666 & $\mathrm{~V}$ \\
\hline 6 & Reference creation & 653 & VI \\
\hline 7 & Inspire curiosity & 647 & VII \\
\hline 8 & Keep brand with customers' top of mind and tip of the dialect & 637 & VIII \\
\hline 9 & Strong marketing communication messages & 585 & IX \\
\hline 10 & $\begin{array}{l}\text { Drive out buying behavior with need, self-esteem, sense of } \\
\text { achievement }\end{array}$ & 569 & $\mathrm{X}$ \\
\hline
\end{tabular}

\section{Interpretation}

It is noticed from the Table 9 that attribute of demonstration of wrist watches features in specific to men and women stood first (I) rank with the weighted average ranking score of 678 that trigger customers' mood to buy the wrist watches and build a community is the next attribute stood second (II) rank with the weighted average ranking score of 676 trigger customers' mood to buy the wrist watches. Attribute of drive out buying behavior with need, self-esteem, and sense of achievement stood tenth $(\mathrm{X})$ rank with the weighted average ranking score of 569 that trigger customers' mood to buy the wrist watches.

\section{Findings of the Study}

$35 \%$ of the respondents said that brand image is first factor that they consider buying the wrist watches and $16 \%$ and $13 \%$ of the respondents said that they consider appearance and durability respectively to buy the wrist watches. Only $1 \%$ of the respondents said that they consider after sales service as the factor to buy the wrist watches.

$29 \%$ of the respondents said that style is the main reason for buying a new wrist watches and only $1 \%$ of the respondents said that they buy the wrist watches for gifting purpose.

$27 \%$ of the respondents wish to buy for fashionable and $24 \%$ of the respondents said that all in one category of watches are the next preference.

$53 \%$ of the respondents preferred price band on the selection of wrist watches fall up to Rs.5000 and only $1 \%$ of the respondents said that their preferred price band on the selection of wrist watches between Rs.20001 to Rs.25000.

$52 \%$ of the respondents have an opinion that their point of cognition happens outside of individuals' conscious brain and $48 \%$ of the respondents have an opinion that their point of cognition happens inside of individuals' sub conscious and emotional brains.

$90 \%$ of the respondents have an opinion that customers' attention can be shaped by triggering of emotional brains and mood and $10 \%$ of the respondents have an opinion that customers' attention can't be shaped by triggering of emotional brains and mood.

Attribute of demonstration of wrist watches features in specific to men and women stood first (I) rank with the weighted average ranking score of 678 that trigger customers' mood to buy the wrist watches and build a community is the next attribute stood second (II) rank with the weighted average ranking score of 676 trigger customers' mood to buy the wrist watches. Attribute of drive out buying behavior with need, self-esteem, and sense of achievement stood tenth $(\mathrm{X})$ rank with the weighted average ranking score of 569 that trigger customers' mood to buy the wrist watches.

\section{Suggestions of the Study}

It is suggested that jewelry and watches segment must focus more on the measures/attributes that trigger customers' mood to buy the wrist watches as detailed in the framework and it would result in moments of truth, stimuli on purchase of product.

It is also suggested that marketers must appropriately design the strategy to stimulate point of cognition of customers that would happen either inside of individuals' sub conscious and emotional brains or outside of individuals' conscious brain.

\section{Conclusion}

It is concluded that attribute of demonstration of wrist watches features in specific to men and women, building a community group and attribute of need, elite and self-esteem, sense of accomplishment, aspiration, and marketing communication tactics are some of the significant attributes that trigger the customers to buy wrist watches from highest order to lowest order.

\section{Scope for Further Research}

The present study focused on gender-based mood analysis on purchase of wrist watches. Given the fact, further research can be carried out to analyze the mood of respondents on purchase of other product categories and can be on what triggers the mood of the respondents to buy the other product categories.

\section{References}

Clark, D. M., \& Teasdale, J. D. (1985). Constraints on the effects of mood on memory. Journal of Personality and Social Psychology, 48(6), 15951608. Available at: https://doi.org/10.1037/0022-3514.48.6.1595. 
Gardner, M. P., \& Ronald, P. H. (1986). Consumers' mood states: Antecedents and consequences of experiential Vs. Informational strategies for brand choice," Working Paper. New York: New York University.

Gasper, K. (2003). When necessity is the mother of invention: Mood and problem solving. Journal of Experimental Social Psychology, 39(3), 248-262. Available at: https://doi.org/10.1016/s0022-1031(03)00023-4.

Rook, D., \& Meryl, P. G. (1986). Mood factors and impulsive buying behavior. Los Angeles, CA: Working Paper, University of Southern California.

Rothkopf, J. S., \& Blaney, P. H. (1991). Mood congruent memory. The role of affective focus and gender. Cognition and Emotion, 5(1), 53-64. Available at: https://doi.org/10.1080/0269993910841 1023.

Watson, J. (2001). How to determine a sample size: Tip sheet \#60. University Park, PA: Penn State.

Zaltman, G. (2016). Marketing's forthcoming age of imagination. Academy of Marketing Science Review, 6(3), 99-115. Available at: https://doi.org/10.1007/s13162-016-0082-3. 